\title{
MODEL PEMBELAJARAN INOVATIF: Meningkat Pemahaman Siswa Pada Teks Anekdot Melalui Dialog
}

\author{
Niken Aulia \\ E-mail: nikenaulia003@gmail.com \\ Program Studi Pendidikan Bahasa dan Sastra Indonesia, Universitas Riau
}

\section{Pengantar}

Pembelajaran yang bisa dikatakan sukses atau berhasil salah satunya siswa mampu memahami materi yang disampaikan oleh guru dengan baik. Di sisi lain, pembelajaran yang gagal dapat dikatakan dengan ketidakmampuan siswa dalam memahami materi pembelajaran. Dalam artian tidak bisa dikatakan sepenuhnya salah seorang guru jika hanya satu atau dua orang siswa tidak mampu memahami materi yang disampaikan. Hal ini menandai bahwa kurangnya daya tangkap siswa dalam memahami materi yang disampaikan guru.

Setiap guru memiliki ciri khas tersendiri dalam menyampaikan materi pembelajaran kepada siswanya. Dengan ciri khas yang dimiliki setiap guru ini bertujuan agar siswa mampu memahami materi yang disampaikan dengan baik. Tentunya setiap guru juga sudah mengetahui tingkat kepemahaman setiap siswanya dalam memahami materi yang disampaikan. Dengan mengetahui tingkat kepemahaman siswanya, guru berperan sangat besar dan memiliki berbagai cara agar mampu membuat siswanya paham mengenai materi pembelajaran.

Dalam mencapai hasil belajar yang maksimal maka dibutuhkan sikap serta motivasi dalam belajar yang tinggi pada siswa. (Zulhafizh, Atmazaki, \& Syahrul, 2013). Sikap ini juga muncul diawali dengan kesukaan siswa terhadap guru dalam menyampaikan materi pembelajaran. Setiap guru tentu sudah melakukan cara-cara dalam penyampaian materi agar siswa mampu memahami materi yang disampaikan dengan baik. Jika satu cara tidak mampu membuat siswa paham maka guru akan mengganti dengan cara lain dalam penyampaian materi agar siswanya paham.

Dalam penyampaian materi pembelajaran, tentu juga melihat mengenai materi yang akan disampaikan oleh guru. Dalam menyajikan materi tentu juga perlu menyesuaikan dengan cara penyampaian yang tepat. Penyesuain ini tentu bertujuan agar siswa mampu memahami dengan tepat materi yang disampaikan oleh guru terhadap siswanya. Salah satu penyampaian materi yang dilakukan oleh guru terhadap siswanya yaitu dengan narasi. 
Dengan berkembangnya zaman yang semakin maju dari hari ke hari. Tentunya pola pikir setiap guru juga harus berkembang dalam penyampaian materi pembelajaran terhadap siswa. Berbagai teknologi mampu mendukung proses pembelajaran antara guru dan siswa di sekolah. Hal ini tentunya tidak boleh ditinggalkan dan disiakan begitu saja oleh guru, karena kita guru harus bergerak maju dalam proses pembelajaran.

Pada artikel ini, terdapat sebuah inovasi dalam penyampaian materi yang dilakukan oleh guru pada teks anekdot. Penyampaian materi yang dilakukan biasanya pada teks anekdot adalah berupa narasi. Cara penyampaian berupa narasi dalam teks anekdot sering kali membuat siswa kesulitan dalam memahami materi yang disampaikan. Oleh karena itu, pada artikel ini akan merujuk pada penyampaian materi teks anekdot dengan melibatkan siswa secara aktif dalam berdialog.

\section{Tindakan yang Dilakukan}

\section{a. Media Pembelajaran Teks Anekdot Di Sekolah}

Teks Anekdot adalah sebuah teks yang mengandung lelucuan dan humor didalamnya. Teks anekdot adalah teks yang berbentuk cerita, di dalamnya termuat humor dan kritikan (Triyani, Romdon, Mekar, \& Siliwangi, 2018). Teks anekdot ini juga dikatakan berupa teks singkat, teks yang mengesankan dan menarik. Pada umumnya teks anekdot yang mengikuti strukturnya akan membuat orang tertawa saat membacanya.

Teks anekdot yang terkesan lucu dan menarik tentu memiliki tujuan tertentu yang ingin disampaikan kepada yang ditujukan. Teks anekdot yang mengandung kritikan ini disampaikan secara halus oleh penulis kepada orang yang membacanya atau kepada orang tertentu yang ditujukan. Kritikan ini bersifat mendukung yang tentunya nanti tidak akan menjatuhkan orang yang ditujukan. Dengan adanya kritikan ini terdapat lelucuan didalamnya agar terkesan lebih bermakna.

Teks anekdot adalah salah satu bahan ajar yang terdapat didalam kurikulum Sekolah Menengah Atas. Artinya guru Bahasa Indonesia SMA wajib memberikan bahan materi pembelajaran teks anekdot pada siswa mereka. Meskipun teks ini terkesan lucu tetapi terkandung kritikan didalamnya yang membangun. Dengan terdapatnya teks anekdot didalam kurikulum pendidikan SMA maka siswa harus benar-benar memahami mengenai teks anekdot. 
Pada umumnya, di Sekolah Menengah Atas teks anekdot disampaikan oleh guru kepada siswanya berupa bahan pembelajaran dalam bentuk teks. Guru hanya berfokus pada buku atau LKS yang dimilikinya sebagai bahan ajar yang akan disampaikan kepada siswanya. Guru menyampaikan pengertian teks anekdot, struktur teks anekdot, unsur kebahasaan teks anekdot dan contoh teks anekdot. Semua bahan mengenai teks anekdot diambil dari buku paket yang dimiliki oleh guru tersebut.

Dalam penyampaian materi kepada siswa mengenai teks anekdot ini, guru menggunakan penyampaian secara naratif dan deskriptif kepada siswa. Dalam proses pembelajaran ini guru berperan sangat aktif dan siswa berperan pasif. Hal ini terbukti dengan guru yang menyampaikan bahan ajar dengan narasi artinya menjelaskan dan deskriptif berupa menggambarkan kepada siswa mengenai teks anekdot. Dalam artian guru menjelaskan dan menggambarkan secara luas tetapi siswa hanya mendengarkan yang nantinya siswa akan merujuk pada siswa pasif.

Pada umumnya penyampaian materi oleh guru secara naratif dan deskriptif dengan pengetahuan luas yang bahan materi ajar diambil dari buku paket belum tentu membuat siswa paham mengenai materi tersebut. Hal ini disebabkan oleh guru yang berperan aktif, sedangkan siswa hanya bisa mendengarkan penjelasan materi yang disampaikan oleh guru. Beberapa siswa aktif pasti akan bertanya kepada guru mengenai beberapa hal yang tidak mereka ketahui dan mereka pahami dari penjelasan gurunya. Hal ini berbeda dengan siswa yang memang pasif di kelas, mereka akan sulit memahami jika mereka dari awal sudah tidak mengerti dengan bahan ajar yang disampaikan.

Setelah guru menjelaskan secara naratif dan deskriptif mengenai bahan materi teks anekdot pada siswa. Pada umumnya guru akan meminta siswa untuk mengerjakan beberapa tugas latihan seperti membuat teks anekdot. Dalam hal ini sering kali siswa mengalami kesulitan saat membuat tugas tersebut. Hal ini disebabkan siswa yang tidak berperan secara aktif atau tidak terlibat langsung dalam proses pembelajaran berlangsung.

Proses pembelajaran tidak bisa dikatakan hal yang sederhana, tetapi suatu aktivitas yang kompleks (Zulhafizh , 2021). Seorang guru harus benar-benar menjelaskan materi dengan baik agar siswa mampu memahami materi yang disampaikan padanya sebagai bahan ajar. Tentunya guru harus merubah pola cara mengajar ke arah yang bisa membuat siswa mampu memahami materi yang disampaikan. Salah satu inovasi yang dapat dilakukan yaitu dengan berdialog yang melibatkan banyak siswa. 


\section{b. Inovasi Materi Pembelajaran Teks Anekdot Disampaikan Secara Berdialog}

Untuk memproduksi teks anekdot yang benar serta dapat meningkatkan pengetahuan siswa, cara yang tepat yaitu siswa dapat menggunakan video (Rifjiana, 2015). Dengan video akan membuat siswa secara langsung memahami dan mampu memaknai video yang ditampilkan. Hal ini tentu akan membuat siswa lebih cepat dalam menangkap apa yang disedang dibahas. Tidak hanya itu, siswa juga tidak kesulitan dalam mempratikkan.

Materi yang disampaikan oleh guru pada siswa juga bisa dilakukan pada penampilan slide ppt dari laptop menggunakan infokus. Dengan hal ini siswa mampu melihat secara langsung bentuk paparan materi yang akan dibahas. Dengan adanya penampilan materi dalam bentuk ppt secara menarik juga akan membuat siswa tidak merasa bosan dan adanya hal baru yang dijumpai dalam proses pembelajaran. Dengan hal ini, guru juga dapat menyampaikan secara langsung paparan materi yang disampaikan.

Setelah paparan materi disampaikan dengan paparan ppt maka guru juga bisa menampilkan video teks anekdot dalam bentuk dialog. Tentunya dalam menampilkan video itu, guru tidak hanya diam saja tapi juga menjelaskan bagian-bagian struktur dari teks anekdot. Dengan menjelaskan sembari menampilkan video tersebut maka siswa akan mudah memahami mengenai materi yang disampaikan. Tidak hanya mudah dalam memahami pengertian teks anekdot tetapi siswa juga mampu membedakan bagian-bagian dari struktur teks anekdot.

Dengan pemahaman yang baik maka juga mampu membuat siswa untuk berkreatifitas dengan ide-ide mereka yang lebih cemerlang. Pemahaman yang baik juga akan menumbuhkan semangat belajar yang kuat pada siswa. Hal ini tentu membuat siswa lebih ingin menggali ilmu lebih dalam lagi. Jika pemahaman tidak mereka miliki maka akan muncul rasa bosan dan tidak ingin melanjutkan untuk mencari tahu pengetahuan lebih luas lagi.

Untuk membuktikan siswa paham atau tidak mengenai materi yang disampaikan guru juga bisa melibatkan siswa secara langsung dalam mempratikkan teks anekdot dalam berdialog sesuai video yang ditampilkan. Dalam mempratikkan ini siswa ditunjuk secara langsung maju ke depan untuk beralog mengenai anekdot dan akan terlihat nantinya siswa yang paham atau tidak. Dengan hal ini siswa yang paham akan lebih paham. Untuk siswa yang tidak paham, guru akan membantunya untuk memahami materi kembali dalam berdialog mengenai teks anekdot. 
Hal yang perlu dilakukan guru juga berbentuk memberikan tugas kepada siswa dan siswinya. Tugas ini dalam bentuk kelompok dengan beberapa anggota didalamnya. Guru meminta mereka untuk membuat teks anekdot secara berkelompok lalu mempratikkan kembali tugas itu dalam bentuk berdialog di depan kelas. Tentunya dalam tugas ini juga memerhatikan ketentuan-ketentuan dalam membuat teks anekdot.

Dengan menggunakan metode pembelajaran ini, membuat siswa akan lebih aktif dalam belajar. Tidak hanya itu, siswa juga lebih mudah memahami materi pembelajaran yang sedang dilaksanakan dan mengetahui secara mendalam bagian-bagian dari teks anekdot tersebut. Selain mudah memahami materi pembelajaran siswa juga merasa tidak bosan dalam belajar. Hal ini dapat dilakukan sebagai inovasi untuk kemajuan dalam proses pembelajaran.

\section{Sarana Pendukung}

a. Laptop

Laptop ini digunakan untuk menampilkan materi dalam bentuk ppt dan video yang membahas tentang teks anekdot dan ditujukan kepada siswa agar mampu memahami slide yang ditampilkan oleh guru.

b. Infokus

Infokus ini digunakan untuk menampilkan materi dalam bentuk ppt dan video yang ada dilaptop. Arah dari layar infokus biasanya ditancapkan pada layar proyektor tetapi sebagian guru juga menggunakan papan tulis sebagai layar proyektornya.

c. Kabel Listrik Panjang.

Kabel listrik panjang ini digunakan untuk bisa menyambungkan infokus serta laptop pada listrik.

\section{Tindakan Solutif}

a. Jika listrik mati otomatis guru tidak bisa menggunakan laptop untuk menampilkan materi pembelajaran maka guru dapat menggunakan buku paket atau LKS sebagai bahan menyampaikan materi.

b. Jika listrik mati otomatis guru tidak bisa menggunakan laptop untuk menampilkan materi maka guru bisa menggunakan spidol dan papan tulis untuk menyampaikan dan menjelaskan bahan materi kepada siswa. 
c. Jika infokus tidak ada atau sedang digunakan oleh guru lain maka guru tidak bisa menampilkan contoh video teks anekdot untuk diperlihatkan pada siswa maka untuk memberikan contoh teks anekdot pada siswa dalam bentuk dialog, guru bisa mengatur beberapa siswa dalam berdialog untuk mencontohkan teks anekdot sesuai dengan struktur teks anekdot.

\section{Simpulan}

Mengajar bukan hanya sekedar memberikan materi kepada siswa tetapi guru juga berperan besar dalam mendidik, mengarahkan dan mengantarkan siswa ke masa depan yang lebih cerah. Tidak hanya, itu guru juga berperan sangat besar untuk membuat siswa mampu memahami disetiap pembelajaran yang sedang dibahas atau didiskusikan. Dengan kepemahaman siswa dalam memahami materi pembelajaran membuatnya menambah pengetahuan secara luas. Dengan pengetahuan yang luas tentu siswa akan semakin semangat dalam menuntut ilmu.

Dalam proses pembelajaran tentu tidak mudah bagi guru untuk menghadapi siswanya. Setiap guru juga harus memahami karakter siswanya dan mengetahui tingkat kepemahaman yang dimiliki siswa. Hal ini bertujuan agar guru mampu mengatasi atau mampu mengetahui cara menghadapi disetiap karakter siswa. Selain itu, guru juga mampu untuk memilah cara mana yang paling tepat untuk diajarkan kepada siswa agar siswanya menjadi paham.

Untuk kemajuan proses pembelajaran tentu saja tidak terus menerus berada pada cara yang telah ada. Hal ini dibutuhkan inovasi agar pembelajaran terus berkembang dan lebih maju. Setiap guru harus melakukan inovasi agar guru mampu untuk terus menerus belajar dan mengajak siswanya kearah lebih maju serta luas pengetahuananya. Oleh sebab itulah, perlunya inovasi pendidikan pada proses pembelajaran salah satunya pada bahan ajar teks anekdot yang biasanya disajikan dalam bentuk naratif dan deskriptif, berubah pada bahan ajar teks anekdot yang disajikan dalam bentuk dialog.

\section{Referensi}

Rifjiana, P. M. (2015). Peningkatan Keterampilan Memproduksi Teks Anekdot Berbentuk Dialog Menggunakan Pendekatan Saintifik Dengan Media Audiovisual. 
Triyani, N., Romdon, S., Mekar, I., \& Siliwangi, I. (2018). PENERAPAN METODE DISCOVERY LEARNING Pada Pembelajaran Menulis Teks Anekdot. Jurnal Pendidikan Bahasa dan Sastra Indonesia, 1(5).

Zulhafizh . (2021). Peran dan Mutu Pelaksanaan Pembelajaran oleh Guru di Satuan Pendidikan Tingkat Atas. Jurnal Hasil Penelitian dan Kajian Kepustakaan di Bidang Pendidikan, Pengajaran dan Pembelajaran.

Zulhafizh, Atmazaki, \& Syahrul, R. (2013). Kontribusi Sikap dan Motivasi Belajar Siswa Terhadap Hasil Belajar Bahasa Indonesia. Jurnal Bahasa Sastra dan Pembelajaran, 1328. 


\section{*Data Penulis}

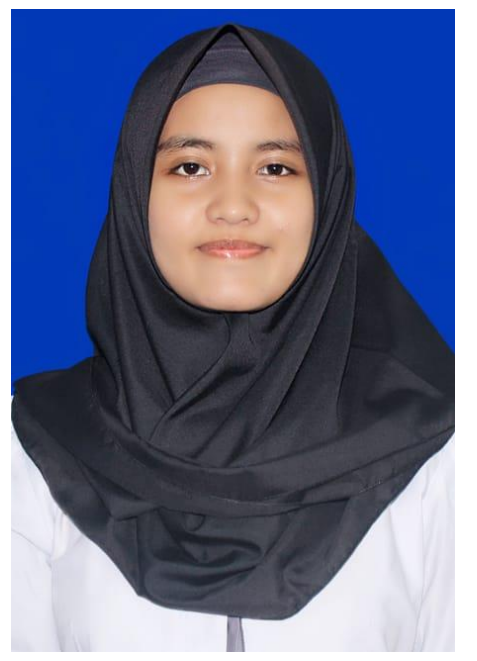

Niken Aulia, lahir di Pasarbaru Pangean, 25 Maret 2002. Ia merupakan anak bungsu dari empat bersaudara. Pada tahun akademik 2020, ia lulus dari Man 2 Kuantan Singingi. Setelah lulus, ia melanjutkan kuliah di Jurusan Pendidikan Bahasa dan Seni di Program Studi Pendidikan Bahasa dan Sastra Indonesia FKIP Universitas Riau melalui jalur SNMPTN dan sekarang masih berstatus mahasiswa. Sederet prestasi yang sudah ia raih selama menjalani Pendidikan yaitu Juara 1 Cabang Tenis Meja Putri Tingkat Kabupaten, Juara 2 English Camp Pare AEC, dan sudah menghasilkan beberapa cerpen dan puisi yang belum dibukukan.

Kontak

Hp/WA : :082237604878

Email : nikenaulia003@gmail.com 